\title{
Peningkatan Aktivitas dan Hasil Belajar Matematika Materi Perkalian dan Pembagian Melalui Model Pembelajaran Jigsaw dengan Media Kartu Bilangan
}

\section{Harminah* $^{*}$}

SD 2 Kaliwungu Kudus

\section{A R T I C L E I N F O}

Article history:

Received 12 December

2019

Received in revised form

01 January 2020

Accepted 30 January 2020

Available online 27

February 2020

\section{Kata Kunci:}

Aktivitas dan Hasil

Belajar, Model Jigsaw

Keywords:

Activities and Learning

Outcomes, Jigsaw Model

\begin{abstract}
A B S T R A K
Penelitian bertujuan untuk meningkatkan aktivitas dan hasil belajar Matematika materi perkalian dan pembagian melalui model pembelajaran Jigsaw dengan media kartu bilangan pada siswa kelas II SD 2 Kaliwungu semester II tahun pelajaran 2017/2018. Prosedur pelaksanaan dan implementasi penelitian terbagi dalam dua siklus. Siklus I dilakukan dua kali pertemuan dan begitu juga siklus II dilakukan dua kali pertemuan. Pada akhir tindakan siklus I aktivitas belajar siswa sebesar $72,38 \%$ meningkat pada siklus II menjadi $89,5 \%$. Selanjutnya, rata-rata nilai tes formatif siklus I sebesar 69,50 meningkat pada siklus II menjadi 76,50 . Ketuntasan belajar klasikal pada siklus I sebesar $65 \%$ meningkat pada siklus II menjadi $85 \%$ sehingga mengalami peningkatan sebesar 20\%. Disimpulkan bahwa melalui model Jigsaw dengan media kartu bilangan terbukti dapat meningkatkan aktivitas dan hasil belajar Matematika. Disarankan bahwa, pada proses pembelajaran guru harus mampu menciptakan suasana belajar yang menyenangkan serta melibatkan aktivitas seluruh siswa.
\end{abstract}

\section{A B S T R A C T}

The research aims to improve the activities and learning outcomes of Mathematics multiplication and division material through the Jigsaw learning model with number card media in class II Kaliwungu Elementary School students in the second semester of the 2017/2018 academic year. The procedure of implementing and implementing research is divided into two cycles. Cycle I held two meetings and so did cycle II held two meetings. At the end of the first cycle of student learning activities by $72.38 \%$ increased in the second cycle to $89.5 \%$. Furthermore, the average value of the formative test for the first cycle of 69.50 increased in the second cycle to 76.50. Classical learning completeness in the first cycle by $65 \%$ increased in the second cycle to $85 \%$ so that it increased by $20 \%$. It was concluded that through the Jigsaw model with number card media was proven to be able to increase Mathematics activities and learning outcomes. It is recommended that, in the learning process the teacher must be able to create a pleasant learning atmosphere and involve the activities of all students. 


\section{Pendahuluan}

Dalam kegiatan pembelajaran Matematika kelas II SD 2 Kaliwungu Kudus, guru masih menggunakan metode pembelajaran konvensional, sehingga membuat pembelajaran menjadi monoton dan membosankan bagi siswa. Akibatnya, hasil belajar kurang memuaskan bahkan masih ada di bawah kriteria ketuntasan belajar. Hal ini didukung data perolehan nilai siswa pada materi perkalian dan pembagian, hanya 8 siswa atau sekitar 40\% dari 20 siswa di atas KKM 65. Berdasarkan hasil analisis pembelajaran di kelas II SD 2 Kaliwungu masih terpusat pada guru, dalam hal ini guru belum optimal menggali aktivitas dan potensi siswa, keterlibatan siswa dalam proses pembelajaran kurang optimal sehingga berpengaruh terhadap hasil belajar siswa.

Menurut Rosyidah (2016) untuk meningkatkan mutu pendidikan, bangsa Indonesia mencanangkan program wajib belajar selama sembilan tahun. Dalam program tersebut diharapkan seluruh anggota masyarakat mendapatkan kesempatan untuk memperoleh pendidikan dimana kecerdasan dan kemampuannya dapat dikembangkan secara optimal melalui proses belajar. Belajar mengandung dua pokok pengertian yaitu proses dan hasil belajar. Proses belajar di sini dapat dimaknai sebagai suatu kegiatan dan usaha untuk mencapai perubahan tingkah laku, sedangkan perubahan tingkah laku tersebut merupakan hasil belajar. Belajar memegang peranan penting dalam perkembangan, kebiasan, sikap, keyakinan, tujuan, kepribadian, bahkan persepsi seseorang. Konsep tentang belajar telah banyak didefinisikan oleh pakar pendidikan. Belajar menurut ahli berbeda-beda, tergantung pada sudut pandang dan pola pikir. Menurut Hamdani (2011:20) belajar adalah suatu proses usaha yang dilakukan seseorang untuk memperoleh perubahan tingkah laku yang baru secara keseluruhan, sebagai hasil pengalamannya sendiri dalam interaksi dengan lingkungannya. Sudjana (2011:28) mengemukakan belajar adalah proses mereaksi terhadap semua situasi yang ada di sekitar individu. Belajar dapat dipandang sebagai proses yang diarahkan kepada tujuan dan proses berbuat melalui berbagai pengalaman. Siswa merupakan unsur penentu dalam proses pembelajaran. Tujuan yang harus dicapai dari proses pembelajaran adalah perubahan perilaku siswa. Kegiatan pembelajaran tidak lepas dari segala aktivitas belajar yang dilakukan siswa. Menurut Hamdani (2011:137) aktivitas belajar (learning activity) adalah perubahan aktivitas jiwa yang diperoleh dalam proses pembelajaran dari kegiatan mengamati, mendengarkan, menanggapi, berbicara, kegiatan menerima, dan kegiatan merasakan. Dalam kegiatan belajar sangat diperlukan adanya aktivitas, tanpa aktivitas belajar itu tidak mungkin akan berlangsung dengan baik. Aktifnya siswa selama proses belajar mengajar merupakan salah satu indikator adanya keinginan atau motivasi siswa untuk belajar yang optimal. Hasil belajar menurut Dimyati dan Mudjiono (2009:3-4), merupakan hasil dari suatu interaksi tindak belajar dan tindak mengajar. Dari sisi guru, tindak mengajar diakhiri dengan proses evaluasi hasil belajar. Dari sisi siswa, hasil belajar merupakan berakhirnya penggal dan puncak proses belajar. Sedangkan menurut Anni dkk (2007:9) hasil belajar merupakan perubahan perilaku yang diperoleh siswa setelah mengalami aktivitas belajar. Jadi, hasil belajar merupakan produk dari proses kegiatan belajar yang berupa perubahan kemampuan baik pengetahuan, sikap, maupun perilaku. Kemampuan tersebut diperoleh dari hasil aktivitas siswa yang belajar. Menurut Syarifuddin (2011) Guru sebagai penyelenggara dalam kegiatan pembelajaran bukan hanya berperan membelajarkan siswa tetapi berperan lebih dalam meningkatkan motivasi dan juga memperoleh hasil belajar yang optimal dalam sebuah proses belajar mengajar yang harus selalu dilakukan secara optimal dan maksimal. Bukan rahasia umum lagi jika pembelajaran di madrasah/sekolah masih sering diidentikkan dengan proses pembelajaran tradisional yang lebih banyak mengandalkan tradisional dan metode ceramah dalam pembelajarannya. Karena ceramah lebih mendominasi suatu proses pembelajaran, Maka menjadi tidak aneh jika kebanyakan dan hampir semua alumni madrasah/sekolah terbentuk menjadi sosok yang sulit untuk memecahkan persoalan yang dihadapi, kurang kritis dan terkesan tidak terbuka dan tidak perduli terhadap berbagai wacana baru yang muncul di masyarakat.

Salah satu model pembelajaran yang dapat menciptakan suasana belajar yang menyenangkan dan keterbukaan dari guru yaitu model Jigsaw dengan media kartu bilangan. Menurut Putra (2018) Model pembelajaran ini didesain untuk meningkatkan rasa tanggung jawab siswa terhadap pembelajarannya sendiri dan juga pembelajaran orang lain. Siswa tidak hanya mempelajari materi yang diberikan, tetapi mereka juga harus siap memberikan dan mengajarkan materi tersebut kepada kelompoknya. Sehingga baik kemampuan secara kognitif maupun sosial siswa sangat diperlukan. Model pembelajaran Jigsaw ini diladasi oleh teori belajar. Menurut Alfazr (2016) Model pembelajaran jigsaw mampu menangani permasalahan siswa yang kurang memiliki sikap kerjasama yang baik dengan temannya pada saat berkelompok. Pada model ini, siswa akan bekerjasama dengan teman-temannya karena di dalam penerapan model pembelajaran jigsaw ini, siswa dihadapkan pada dua kelompok yang berbeda yaitu kelompok asal dan kelompok ahli. Dengan demikian, mau tidak mau siswa harus bekerjasama, meminta 
pendapat, mengusulkan pendapat, dan tentunya saling menghargai pendapat antar temannya di kelompok asal maupun di kelompok ahli. Dengan model jigsaw diharapkan proses pembelajaran lebih terpusat pada siswa. Siswa tidak hanya sebagai penerima informasi, tetapi siswa berperan aktif dalam pembelajaran. Model Jigsaw juga memberikan kesadaran bagi para pembelajar khususnya siswa tentang pentingnya pembelajaran yang demokratis, saling membelajarkan dalam memberdayakan potensi siswa secara optimal sehingga lebih bermakna dan menyenangkan. Pembelajaran kooperatif tipe Jigsaw merupakan salah satu tipe pembelajaran kooperatif yang mendorong siswa aktif dan saling membantu dalam menguasai materi pelajaran untuk mencapai prestasi yang maksimal (Isjoni 2011:77). Model pembelajaran Jigsaw didesain untuk meningkatkan rasa tanggung jawab siswa terhadap pembelajarannya sendiri dan juga pembelajaran orang lain. Siswa tidak hanya mempelajari materi yang diberikan, tetapi mereka juga harus siap memberikan dan mengajarkan materi tersebut kepada kelompoknya, sehingga baik kemampuan secara kognitif maupun sosial siswa sangat diperlukan. Dalam model Jigsaw, guru membagi satuan informasi yang besar menjadi komponen-komponen lebih kecil. Selanjutnya guru membagi siswa ke dalam kelompok belajar kooperatif yang terdiri dari empat orang siswa sehingga setiap anggota bertanggung jawab terhadap penguasaan setiap komponen atau subtopik yang ditugaskan guru dengan sebaik-baiknya. Siswa dari masing-masing kelompok yang bertanggung jawab terhadap subtopik yang sama membentuk kelompok lagi yang terdiri atas dua atau tiga orang. Dengan demikian, setiap siswa dalam kelompok harus meguasai topik secara keseluruhan (Rusman, 2012:217). Langkah-langkah model Jigsaw menurut Rusman (2012:218) adalah sebagai berikut: 1) Siswa dikelompokkan dengan anggota \pm 4 orang (kelompok asal); 2) Tiap orang dalam tim diberi materi dan tugas yang berbeda; 3) Anggota dari tim yang berbeda dengan penugasan yang sama membentuk kelompok baru (kelompok ahli); 4) Setelah kelompok ahli berdiskusi, tiap anggota kembali ke kelompok asal dan menjelaskan kepada anggota kelompok tentang subbab yang mereka kuasai; 5) Tiap tim ahli mempresentasikan hasil diskusi; 6) Pembahasan; dan 7) Penutup.

Tujuan penelitian ini adalah untuk meningkatkan aktivitas dan hasil belajar Matematika materi perkalian dan pembagian melalui model pembelajaran Jigsaw dengan media kartu bilangan pada siswa kelas II SD 2 Kaliwungu Semester II Tahun Pelajaran 2017/2018.

\section{Metode}

Penelitian tindakan kelas dilakukan di kelas II SD 2 Kaliwungu Kudus semester II tahun pelajaran 2017/2018 dengan subjek 20 siswa. Teknik pengumpulan data dengan mendeskripsikan hasil tes dilakukan secara langsung kepada siswa untuk memperoleh data tentang hasil belajar siswa pada proses pembelajaran secara benar dan tepat. Metode tes digunakan untuk memperoleh data tentang tingkat kemampuan penguasaan materi pembelajaran sebelum dan sesudah pembelajaran.

Teknik analisis melalui dua tahap, yaitu 1) menggunakan teknik analisis deskriptif yaitu hasil tes dari kondisi awal, siklus I dan siklus II, sehingga setelah dibandingkan hasil siklus I dan hasil siklus II ada perbedaan dan peningkatan; dan 2) menggunakan teknik observasi dengan analisis diskriptif berdasarkan hasil observasi dan refleksi. Selanjutnya dari hasil belajar siswa sebelum dilaksanakan pembelajaran model Jigsaw dibandingkan dengan hasil sesudah dilaksanakan model pembelajaran Jigsaw dengan media kartu bilangan untuk mengetahui kemajuan hasil belajar yang dicapai dalam pembelajaran.

Ketercapaian hasil penelitian ini dengan Indikator keberhasilan tindakan kelas tampak apabila peningkatan hasil belajar mencapai 80\% ketuntasan dari jumlah siswa dengan nilai di atas KKM (65).

Penelitian dilaksanakan dua siklus, setiap siklus meliputi empat tahap kegiatan, yaitu perencanaan (planing), pelaksanaan tindakan (acting), pengamatan (observing) dan refleksi (reflecting).

Pada tahap perencanaan ini, kegiatan yang dilakukan yaitu membuat skenario pembelajaran dengan menyusun RPP yang terdapat proses pembelajaran model Jigsaw dengan media kartu bilangan. Pelaksanaan tindakan (acting) sesuai skenario pembelajaran yang telah direncanakan. Pada tiap-tiap siklus yaitu menerapkan pembelajaran model Jigsaw. Siklus II merupakan hasil pengembangan atas refleksi hasil siklus I.

Pengamatan (observing) pada kegiatan ini untuk mengetahui sejauh mana penguasaan siswa dalam pembelajaran. Observasi dilakukan bersamaan pelaksanaan tindakan dengan menggunakan lembar observasi yang telah dibuat. Aspek-aspek yang diamati adalah keaktifan siswa selama proses pembelajaran berlangsung serta hasil tes pada akhir siklus. Hasil analisis data yang dilaksanakan dalam tahap ini digunakan sebagai acuan untuk melaksanakan siklus berikutnya. 
Refleksi (reflecting) hasil observasi yang meliputi aktifitas siswa selama proses belajar mengajar, hasil tes pada akhir siklus juga kendala-kendala yang dihadapi selama kegiatan pembelajaran dikumpulkan serta dikaji sehingga diperoleh hasil refleksi kegiatan untuk mengetahui perubahan yang terjadi selama menerapkan pembelajaran ini. Hasil analisis data yang dilaksanakan dalam tahap ini digunakan sebagai acuan untuk melaksanakan siklus berikutnya.

Dari penjelasan di atas dapat disimpulkan bahwa penelitian ini menggunakan model penelitian tindakan kelas yang digambarkan dalam bagan sebagai berikut:

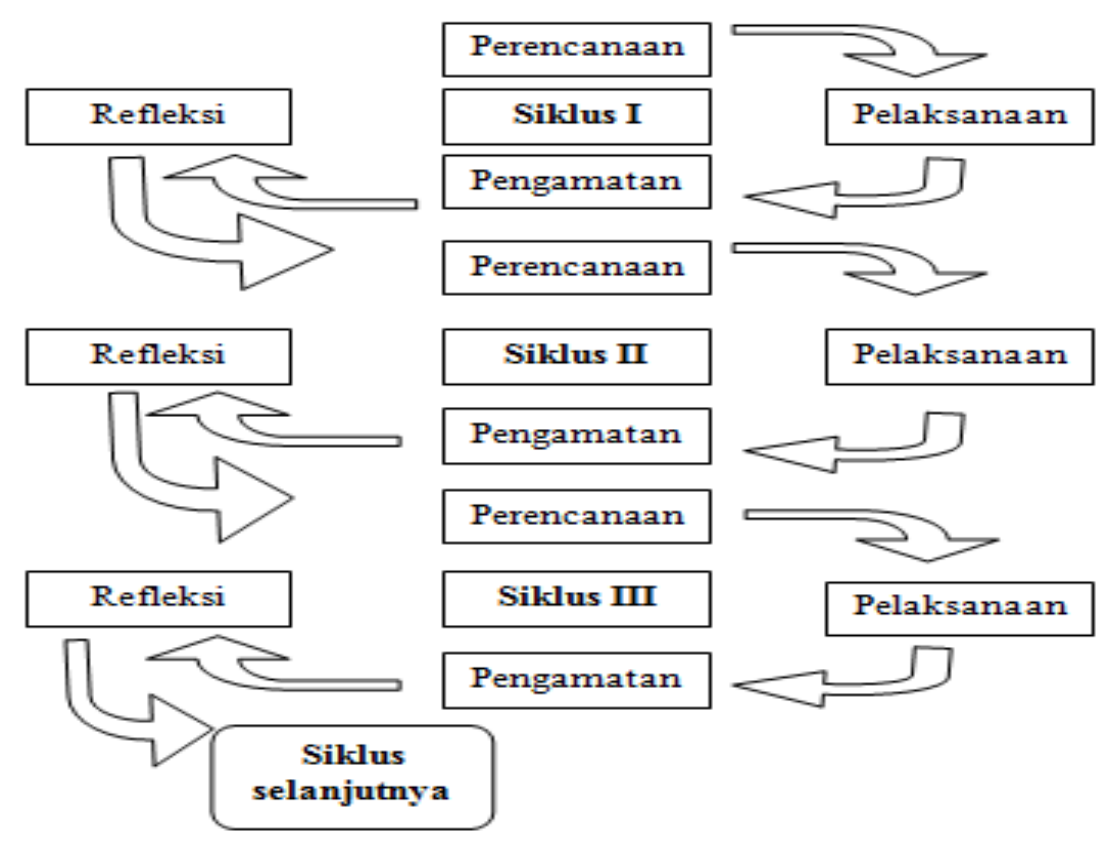

Gambar 1. Model Penelitian Tindakan Kelas

Penjelasan diagram alur PTK di atas adalah: 1) Perencanaan awal, sebelum mengadakan penelitian peneliti menyusun rumusan masalah, tujuan, membuat rencana tindakan, dan perangkat pembelajaran. 2) Tindakan dan observasi, meliputi tindakan yang dilakukan oleh peneliti sebagai upaya membangun pemahaman konsep siswa serta mengamati hasil atau dampak dari diterapkannya model jigsaw dengan media kartu bilangan. 3) Refleksi, peneliti menganalisis, mengkaji, dan mempertimbangkan hasil atau dampak dari tindakan yang dilakukan berdasarkan lembar pengamatan. 4) rencana yang direvisi, berdasarkan hasil refleksi dari pengamat membuat rancangan yang direvisi untuk dilaksanakan pada siklus berikutnya.

\section{Hasil dan Pembahasan}

Kondisi awal hasil belajar siswa kelas II SD 2 Kaliwungu Kudus diketahui bahwa siswa yang sudah memenuhi KKM yaitu $\geq 65$ terdapat 8 siswa (40\%). Hal tersebut dapat dilihat dari jumlah frekuensi siswa yang mendapatkan nilai 65 ke atas. Sedangkan yang belum mencapai KKM $\leq 65$ terdapat 12 siswa (60\%). Hal ini dapat dilihat dari jumlah frekuensi siswa yang mendapatkan nilai 65 ke bawah. Oleh karena itu, perlu dilakukan suatu tindakan pembelajaran guna meningkatkan aktivitas dan hasil belajar matematika kelas II SD 2 Kaliwungu Kudus.

Aktivitas belajar siswa, pada kondisi awal dimana pelaksanaan pembelajaran yang dilakukan oleh guru masih menggunakan metode ceramah atau masih banyak siswa yang pasif, sehingga aktivitas belajar siswa masih rendah. Sedangkan hasil belajar pada kondisi awal dari jumlah siswa yang tuntas (memenuhi KKM) atau rata-rata klasikal: 40\%. Hasil tersebut masih di bawah kriteria ketuntasan klasikal yang ditetapkan sekolah yaitu $80 \%$.

Rendahnya nilai rata-rata siswa yang masih di bawah KKM dan tingkat ketuntasan belajar yang rendah maka peneliti menerapkan model Jigsaw dengan media kartu bilangan. Hasil penilaian dengan pembelajaran yang dilakukan oleh guru melalui model jigsaw dengan media kartu bilangan pada siklus I diperoleh data sebagai berikut. 
Tabel 1. Hasil Belajar Siswa Siklus I

\begin{tabular}{|c|c|c|c|c|}
\hline Rentang Nilai & Kategori & Frek & Nilai & Persen \\
\hline $86-100$ & SB & 2 & 180 & $10 \%$ \\
\hline $76-85$ & Baik & 4 & 320 & $20 \%$ \\
\hline $65-75$ & Cukup & 7 & 490 & $35 \%$ \\
\hline$\leq 65$ & Kurang & 7 & 380 & $35 \%$ \\
\hline Jumlah & & 20 & 1370 & $100 \%$ \\
\hline Rata-Rata & & & 68,50 & \\
\hline Tuntas & $\geq 65$ & 1 & & $65 \%$ \\
\hline Belum Tuntas & $\leq 65$ & 7 & & $35 \%$ \\
\hline
\end{tabular}

Berdasarkan data hasil belajar pada pembelajaran yang dilakukan sudah menunjukkan adanya peningkatan. Pembelajaran yang dilakukan pada prasiklus hanya mencapai ketuntasan $40 \%$ setelah diadakan pembelajaran siklus I menjadi 65\%. Beberapa kekurangan di antaranya: 1) masih banyak siswa yang pasif, 2) keberanian siswa dalam melakukan presentasi masih sedikit, 3) partisipasi siswa dalam diskusi kelompok kurang maksimal. Karena ketuntasan belajar belum mencapai 80\% dari jumlah siswa maka diadakan tindakan perbaikan pembelajaran siklus II dengan cara: 1) mengoptimalkan materi dengan menerapkan model jigsaw dengan media kartu bilangan, 2) meminta kepada semua siswa untuk aktif dalam berdiskusi, karena penyelesaian lembar diskusi siswa yang diberikan guru adalah tanggung jawab seluruh anggota kelompok, 3) memberikan motivasi pada siswa untuk membacakan hasil diskusi, supaya lebih percaya diri dalam mempresentasikan hasil diskusi kelompok dengan penguatan positif.

Kegiatan pembelajaran siklus II berlangsung sangat aktif, siswa antusias melakukan diskusi dan terjadi interaksi harmonis dalam satu kelompok. Siswa saling menanggapi hasil temuan kelompok lain secara rasional dan berpendapat secara logis melalui model jigsaw dengan media kartu bilangan.

Pada tindakan siklus II menunjukkan peningkatan pada hasil belajar siswa. Ketuntasan belajar klasikal yang dicapai sebesar $85 \%$ artinya masih ada 3 siswa (15\%) belum tuntas/mencapai nilai KKM. Hal ini dapat dilihat pada Tabel 2 berikut,

Tabel 2. Hasil Belajar Siswa Siklus II

\begin{tabular}{|c|c|c|c|c|}
\hline Rentang Nilai & Kategori & Frek & Nilai & Persen \\
\hline $86-100$ & SB & 4 & 380 & $20 \%$ \\
\hline $76-85$ & Baik & 6 & 480 & $30 \%$ \\
\hline $65-75$ & Cukup & 7 & 490 & $35 \%$ \\
\hline$\leq 65$ & Kurang & 3 & 180 & $15 \%$ \\
\hline Jumlah & & 20 & 1530 & $100 \%$ \\
\hline Rata-Rata & & & 76,50 & \\
\hline Tuntas & $\geq 65$ & 17 & & $85 \%$ \\
\hline Belum Tuntas & $\leq 65$ & 3 & & $15 \%$ \\
\hline
\end{tabular}

Berdasarkan Tabel 2 diketahui penerapan model pembelajaran Jigsaw dengan media kartu bilangan diperoleh data bahwa ada 17 siswa atau $85 \%$ mengalami ketuntasan belajar $\geq 65$, sedangkan siswa mendapatkan nilai di bawah $\mathrm{KKM} \leq 65$ ada 3 siswa atau sebesar $15 \%$.

Aktivitas belajar siswa pada tindakan siklus II mengalami banyak peningkatan dibandingkan siklus I, hal ini dapat dilihat dari hasil observasi aktivitas siswa pada siklus II sebesar $89,5 \%$. Hasil aktivitas belajar siswa siklus II mengalami peningkatan dari 72,38\% menjadi 89,5\%. Hasil tersebut menunjukkan adanya ketercapaian indikator keberhasilan yakni $\geq 75 \%$. Perolehan peningkatan nilai aktivitas siswa pada siklus II, karena peneliti sudah berhasil membuat siswa lebih memahami model pembelajaran Jigsaw dengan media kartu bilangan yang dilakukan oleh guru.

Pada pembelajaran sebelum tindakan penelitian, peneliti hanya mengandalkan metode konvensional yaitu ceramah, tanya jawab, dan pemberian tugas, sehingga hasil yang dicapai adalah siswa yang memperoleh nilai 65 ke atas hanya 8 dari 20 siswa atau $40 \%$. Dengan nilai terendah 40 , nilai tertinggi 90 dan nilai rata-rata 59. Berdasarkan hasil tersebut peneliti bermaksud untuk meningkatkan aktivitas dan hasil belajar siswa tentang perkalian dan pembagian dengan melaksanakan model pembelajaran Jigsaw dengan media kartu bilangan.

Pada pelaksanaan tindakan siklus I melalui model jigsaw dengan media kartu bilangan, hasil evaluasi yang diperoleh dari 20 siswa ada 13 atau 65\% siswa sudah tuntas belajar, sedangkan 7 atau 35\% 
siswa belum tuntas belajar. Nilai rata-rata kelas yang diperoleh pada tindakan siklus I meningkat dibandingkan pada kondisi awal, ada peningkatan sebesar $25 \%$ sebelum tindakan pembelajaran.

Pada siklus I, diperoleh data rata-rata untuk aktivitas siswa adalah 14,47 atau sebesar 72,38\% dengan kategori cukup baik. Bentuk tindakan yang diberikan pada siklus I berupa penggunaan model pembelajaran Jigsaw dengan media kartu bilangan dalam perkalian dan pembagian. Pembelajaran dilakukan dalam kelompok, menyesuaikan dengan karakteristik siswa kelas II yang sudah mulai bermain dalam kelompok. Proses pembagian kelompok disini ternyata juga memerlukan perhatian khusus, karena pembagian kelompok yang kurang tepat akan membuat kinerja kelompok tersebut tidak optimal.

Pada saat penggunaan model pembelajaran Jigsaw dengan media kartu bilangan, siswa belum berpartisipasi aktif seluruhnya. Penyampaian aturan dalam berkelompok terlalu cepat, beberapa siswa belum dapat bekerjasama dengan baik dalam kelompok dan kurangnya alokasi waktu. Hasil belajar siswa pada siklus I menurut peneliti peningkatannya juga kurang optimal. Peningkatan hasil belajar yang terjadi antara pratindakan dengan siklus I hanya sedikit. Nilai rata-rata pratindakan 59 meningkat menjadi 68,50. Oleh karena itu, penelitian dilanjutkan ke siklus II dengan harapan mendapatkan hasil yang lebih baik.

Hasil tes formatif siklus II mengalami peningkatan. Pencapaian nilai rata-rata kelas pada siklus I mencapai 68,50 dan pada siklus II meningkat menjadi 76,50 . Jumlah siswa yang mengikuti tes formatif yakni 20 siswa. Pada pelaksanaan siklus II terdapat jumlah siswa yang tuntas belajar yaitu 17 siswa dengan persentase ketuntasan belajar 85\%, sedangkan 3 siswa tidak tuntas belajar dengan persentase $15 \%$. Hal ini menunjukkan adanya peningkatan dari siklus I ke siklus II mencapai $20 \%$. Hasil ini termasuk memuaskan karena sudah memenuhi indikator, yang telah ditetapkan yaitu ketuntasan klasikal belajar siswa minimal $80 \%$.

Hasil observasi aktivitas siswa dalam pembelajaran Matematika melalui model kooperatif tipe jigsaw dengan media kartu bilangan pada siklus II, diperoleh jumlah skor rata-rata 17,9 dan persentase 89,5\%. Hasil pengamatan aktivitas siswa untuk siklus II mendapat kriteria sangat baik. Siswa tampak antusias dan bersemangat mengerjakan tugas menggunakan media kartu bilangan. Semua siswa telah mengerjakan tugas, meskipun ada beberapa kesalahan tetapi kesalahannya lebih sedikit dibandingkan pada saat pelaksanaan siklus I. Hampir seluruh siswa aktif dalam kegiatan belajar, meskipun ada beberapa siswa yang masih lambat dalam mengerjakan tugas, hal ini wajar karena kemampuan siswa dalam berfikir berbeda-beda.

Hasil pengamatan siklus II, siswa sudah lebih memahami model pembelajaran jigsaw dengan media kartu bilangan sehingga lebih kondusif dan lebih banyak siswa yang aktif dalam pembelajaran. Siswa lebih mudah diarahkan dalam pembentukan kelompok ahli. Seperti pembelajaran pada siklus I, siswa kembali maju satu-persatu ke depan kelas untuk membentuk kelompok asal yang baru dan berbeda dengan kelompok asal siklus I. Siswa mendapat tugas yang berbeda dalam satu kelompok tanpa berebut dan memilih tugas guru.

Pada siklus II, siswa sudah dapat melaksanakan tugasnya dengan benar. Siswa sudah paham alur kegiatan pembelajaran dan menyadari peran serta tanggung jawabnya dalam kegiatan pembelajaran. Siswa sudah tidak malu lagi untuk berdiskusi dengan teman sekelompoknya. Siswa aktif berdiskusi dan bertanya pada guru saat mengalami kesulitan.

Hasil tes formatif pada pembelajaran Matematika melalui model Jigsaw dengan media kartu bilangan pada siklus II diperoleh data: Nilai tertinggi sebesar 90-100 dicapai 4 siswa dengan persentase $20 \%$ dinyatakan tuntas. Nilai 78-89 diperoleh 6 siswa dengan persentase 30\% tuntas. Nilai 65-77 dicapai 7 siswa dengan persentase $35 \%$ dinyatakan tuntas. Sedangkan nilai terendah $\leq 65$ dicapai 3 siswa dengan persentase $15 \%$ dinyatakan tidak tuntas.

Pelaksanaan tindakan siklus II diperoleh nilai tertinggi 100 dan nilai terendah 60 dengan nilai ratarata 76,50 serta ketuntasan klasikal $85 \%$. Hal tersebut menunjukkan adanya peningkatan jika dibanding dengan hasil belajar pada siklus I dengan nilai terendah 50 dan nilai tertinggi 90 dengan nilai rata-rata 68,50 serta ketuntasan klasikal sebesar 65\%.

Hasil penelitian melalui model pembelajaran Jigsaw dengan media kartu bilangan menunjukkan bahwa hasil belajar siswa, dan aktivitas siswa mengalami peningkatan. Pada data aktivitas siswa dari siklus I ke siklus II mengalami peningkatan sebesar 17,13\%. Selanjutnya, pada data hasil belajar siswa siklus I mengalami peningkatan dari kondisi awal sebesar 25\%, dari siklus I ke siklus II mengalami peningkatan sebesar $20 \%$.

Berdasarkan data yang telah diperoleh dapat disimpulkan bahwa penerapan model pembelajaran Jigsaw dengan media kartu bilangan dapat meningkatkan aktivitas dan hasil belajar Matematika materi perkalian dan pembagian pada siswa kelas II SD 2 Kaliwungu Kudus Semester II Tahun Pelajaran $2017 / 2018$. 


\section{Simpulan dan Saran}

penelitian tindakan kelas yang telah dilaksanakan dapat disimpulkan bahwa: melalui model pembelajaran Jigsaw dengan media kartu bilangan dapat meningkatkan aktivitas dan hasil belajar Matematika materi perkalian dan pembagian pada siswa kelas II SD 2 Kaliwungu Kudus. Hal itu terlihat dari ketuntasan hasil belajar siswa pada siklus II mencapai 85\%, dan respon siswa terhadap penerapan model jigsaw dengan media kartu bilangan sangat baik.

Berdasarkan hasil penelitian pada pembelajaran Matematika materi perkalian dan pembagian melalui model pembelajaran Jigsaw dengan media kartu bilangan pada siswa kelas II SD 2 Kaliwungu Kudus, maka dapat disarankan bagi guru agar dapat mencoba untuk menerapkan model Jigsaw dengan media kartu bilangan dalam proses pembelajaran dan merancang kegiatan pembelajaran sesuai dengan model pembelajaran Jigsaw.

Bagi siswa agar lebih termotivasi untuk belajar dengan adanya inovasi pembelajaran yang diterapkan guru dalam pembelajaran di kelas, sehingga dengan berjalannya waktu akan muncul kesadaran siswa untuk belajar sebagai suatu kebutuhan.

Bagi pihak sekolah perlu menyediakan sarana dan mengambil kebijakan-kebijakan yang mendukung pelaksanaan model pembelajaran kooperatif khususnya Jigsaw, pada berbagai pelajaran.

\section{Daftar Rujukan}

Alfazr, Asep Saiful, Diah Gusrayani, Dede Tatang Sunarya. 2016. Penerapan Model Pembelajaran Jigsaw untuk Meningkatkan Hasil Belajar Siswa dalam Menemukan Kalimat Utama pada Tiap Paragraf. Jurnal Pena Ilmiah: Vol. 1, No. 1 Hal. 111-120. Tersedia Pada: https://ejournal.upi.edu/index.php/penailmiah/article/view/2937.

Anni, Catharina Tri dkk. 2007. Psikologi Belajar. Semarang: UPT UNNES Press.

Dimyati dan Mudjiono. 2009. Belajar dan Pembelajaran. Jakarta: Rineka Cipta

Hamdani. 2011. Strategi Belajar Mengajar. Bandung: Pustaka Setia.

Isjoni. 2011. Cooperative learning Efektivitas Pembelajaran Kelompok.. Bandung: Alfabeta.

Putra, Aziz Ahmadi, Tuti Hardianti, Syahwin,dan Fauzi. 2018. Pengaruh Model Pembelajaran Jigsaw terhadap Hasil Belajar pada Materi Usaha dan Energi. Journalof Physics and Science Learning Vol. 02 Nomor Hal.9-16. 1, Tersedia Pada: https://jurnal.uisu.ac.id/index.php/PASCAL/article/view/608/541.

Ummi Rosyidah. 2016. Pengaruh Model Pembelajaran Kooperatif Tipe Jigsaw terhadap Hasil Belajar Matematika Siswa Kelas VIII SMP Negeri 6 Metro. Jurnal SAP Vol. 1 No. 2 Hal. 115-124. Tersedia Pada: https://journal.lppmunindra.ac.id/index.php/SAP\%20/article/view/1018.

Rusman, 2012. Model-model Pembelajaran Mengembangkan Profesionalisme Guru. Jakarta : Rajawali Pers.

Sudjana, Nana. 2011. Dasar-dasar Proses Belajar Mengajar. Bandung: Sinar Baru Algresindo.

Syarifuddin, Ahmad. 2011. Model Pembelajaran Cooperative Learning Tipe Jigsaw dalam Pembelajaran. Ta'dib, Vol. XVI, No. 02 Hal. 209-226. Tersedia Pada: http://jurnal.radenfatah.ac.id/index.php/tadib/article/download/61/56. 